\title{
The Correlation of Work Duration and Physical Workload with the Complaints of Musculoskeletal Disorders in Informal Workers
}

\author{
Hubungan Lama Waktu Kerja dan Beban Kerja Fisik dengan Keluhan \\ Muculoskeletal Disorders di Pekerja Informal
}

\author{
Nisrina Tiara Sani, Noeroel Widajati \\ Department of Occupational Safety and Health, Faculty of Public Health Universitas Airlangga \\ Campus C Mulyorejo, Surabaya, East Java 60115 Indonesia
}

\begin{abstract}
Introduction: The implementation of protection needs to be given attention and attempted to prevent workers from occupational diseases. One of the occupational diseases that often arises from the incompatibility of worker and their job is Musculoskeletal Disorders (MSDs). This study analyzes the relation between workduration and physical workload with MSDs in informal workers. Methods: An observational research followed by a cross sectional approach was applied as the method of the study. The 23 respondents in the spring production unit were chosen as the sample of the study. The objects of this research were the total population. Data on the characteristics of respondents and MSDs were gained through interviews conducted by filling out standardized questionnaires.Moreover, physical workload was measured using a calorimeter measuring instrument, and MSDs data were analyzed using the NBM measuring tools. Furtermore, the statistical analysis used chi-square test. Results: It shows that there is a relation between work duration and MSDs (p $=0.029)$, and there is a relation between physical workload and MSDs $(p=0.000)$. Conclusion: The risk factors of works duration and physical workload are proven to have a relation with MSDs complaints on workers in informal sector.
\end{abstract}

Keywords: informal workers, musculoskeletal disorders, physical workload, works duration

\begin{abstract}
ABSTRAK
Pendahuluan: Perlindungan terhadap tenaga kerja perlu mendapat perhatian dan diupayakan dalam pelaksanaannya untuk mencegah tenaga kerja terjadi Penyakit Akibat Kerja. Keluhan Musculoskeletal Disorders (MSDs) menjadi suatu penyakit dalam bekerja yang kerap diakibatkan oleh tenaga kerja dengan pekerjaan yang tidak serasi. Penelitian dilaksanakan guna mengetahui hubungan lama waktu kerja dengan beban kerja fisik terhadap keluhan muskuloskeletal pada pekerja di sektor informal. Metode: Penelitian observasional disertai pendekatan cross sectional digunakan pada penelitian ini. Sebanyak 23 responden di unit produksi pegas terpilih sebagai sampel penelitian. Objek penelitian yakni total populasi. Data karakteristik responden dan keluhan musculoskeletal didapatkan dari wawancara yang dilakukan pada responden dari pengisian kuesioner yang di standarisasi. Beban kerja fisik diukur dengan menggunakan alat ukur Kalorimeter dan data keluhan musculoskeletal dianalisis menggunakan alat ukur NBM. Uji statistik memakai uji chisquare. Hasil: Hubungan lama waktu kerja dan keluhan MSDs ( $p=0,029)$ dan hubungan beban kerja fisik dan keluhan MSDs $(p=0,000)$ ditemukan. Simpulan: Faktor risiko lama waktu kerja serta beban kerja fisik berhubungan dengan keluhan MSDs terhadap pekerja di sektor informal..
\end{abstract}

Kata kunci: beban kerja fisik, lama waktu kerja, musculoskeletal disorders, tenaga kerja informal

\section{Corresponding Author:}

Nisrina Tiara Sani

Email: nisrina.tiara.sani-2016@fkm.unair.ac.id

Telephone: +6287822687010

\section{INTRODUCTION}

Occupational health efforts for workers need to be carried out in every workplace, especially for companies or industries that are at risk of health hazards, considering that workers are one of the valuable assets in a company or industry. Therefore, it is important to give attention and protection to workers who have an important role in doing their work. 
Occupational Health and Safety (OHS) is one form of efforts to protect workers in the making of a safe and comfortable workplace. If aspects of OHS are ignored in the work process, it can lead to Occupational Accidents (OAs) and Occupational Diseases (ODs). One of the occupational diseases that often arises from the incompatibility of workers and their job is Musculoskeletal Disorders (MSDs).

This theory is supported by Tarwaka (2015) who states that Musculoskeletal Disorders (MSDs) are complaints that are sensed in parts of skeletal muscle, as a result of forced movement and reception of heavy loads over long periods, resulting in complaints which range from very mild to severe complaints. Therefore, the workload and work duration become one of the causes of musculoskeletal complaints that occur in labors.

According to Tarwaka (2015), human body has been created to be able to perform daily work activities. Muscle mass that weighs almost more than half of body weight allows humans to be able to move the body and do work. Work is a life goal that has an important meaning for progress and improvement in accession so that people can attain a productive life. On the other hand, it also means that the body will receive burdens from outside the body both in the form of physical and mental burdens. Physical workload requires works in the muscles, heart and lungs, which will become more active when the physical workload is getting higher. (Maharja, 2015).

MSDs are defined as the grievance that arise from a very slight to serious pain in the skeletal muscle experienced by an individual. If a muscle repetitively and continuously obtains a static load, then it might aggravate grievance in the form of failure to the ligaments, joints. and also tendons. That complaint is known as musculoskeletal disorders. Tarwaka (2010) outlines that muscle complaints are categorized into two, namely temporary (reversible) complaints and persistent complaints.

Health and Safety Authority (HSA) in 2015 explained that the number of Occupational Diseases (ODs) that occurred in 2012 hit 27.1 out of 1000 workers in Irlandia. The high number of workplace accidents that occur at work has continued to increase since 2012. From the number of reported cases, it is known that around $32 \%$ of workers are suffering from musculoskeletal injuries, resulting from work activities such as lifting weights $(43 \%)$. MSDs accounted for more than 10 percent on the basis of evidence published by the World Health
Organization (WHO) in 2009, which induced impairment (International Labour Organization, 2013).

WHO reports the world's top ten causes of death and illness are due to workplace risk. In the 2017 Global Estimates of Occupational Accidents and Work-Related Illness, the number of workers who died due to occupational diseases in 2015 was 2.4 millions. Meanwhile, in 2016-2017, there were around 507,000 workers in the United Kingdom who suffered from disruption of the musculoskeletal system caused by their occupation.

As shown in the Indonesian Ministry of Health report in 2005, it could be seen that about 40.5 percent of the disorders experienced by labors were linked to their jobs. Disruptions experienced by 9,482 labors in 12 regions in Indonesia were generally in the form of MSDs (16\%), cardiovascular $(8 \%)$, neurological disorders $(5 \%)$, respiratory disorders $(3 \%)$, and ENT disorders $(1.5 \%)$. This finding is in line with a study by Saputra, Naiem and Saleh (2013) discovering that $70 \%$ of their respondents complained about joint muscle pain after work.

The impacts resulting from the emergence of musculoskeletal disorders according to Bird and Germain (2005) are loss of work time, reduction ofalertness, an increase in the risk of accidents. If the complaint has reached the final stage, high costs for recovery are required. Complaints of musculoskeletal disorders require sufficient time and various stages for pain to occur in certain body parts.

Complaints of musculoskeletal disorders can occur in both formal and informal sectors. According to Alma (2001), the informal sector is a manifestation of small-scale employment with the aim of earning income without profit. Business in the informal sector is one type of businesses that has a very high health risk. The workforce in 2000 accounted for $95,650,691$ people, of which $70-80 \%$ were in the informal business sector. Workers in the informal sector are populations who have a lack of health services especially occupational health (Icsal, Sabilu and Pratiwi, 2016).

Informal sector is one of the business fields in Indonesia. Employment in the informal sector has criteria such as a relatively small scale of business, use of simple and manual technology, low income levels, and low skills,. Moreover, not all jobs in the informal sector have clearly written rules such as the work duration, which can be classified as 
flexible. The recommended workduration used by workers in carrying out their work activities should not exceed 8 hours per day, but many jobs do not implement good working time rules. The work usually starts in the morning until the afternoon, even until night. Many workers carry out work that exceeds the recommended working time due to the pursuit of production and the expectation to increase the income that they may receive.

The problem that arises in the informal sector is the lack of knowledge and awareness about the possible threats and dangers that can occur at work area, so that it is more likely to cause higher chance of work accidents and occupational diseases. These activities and working conditions can pose a high risk for the emergence of musculoskeletal complaints in workers.

The explanation above becomes the background for the researchers to conduct research related to the correlation between work duration and physical workload with the occurrence of MSDs in informal workers. It is expected that after - this research was conducted, - the influences related to the incidence of MSDs in labors can be studied. Thus, application of ergonomics in the workplace needs to be pursued directly because it will affect complaints, both fatigue and other health problems. The purpose of the study is to find out the correlation between work duration and physical workload toward MSDs in informal workers.

\section{METHODS}

Observational research was implemented in this study because it did not provide treatment to respondents. Meanwhile, cross-sectional study was applied as the design of this research as variables were studied and observed in the same period of time to describe the level of Musculoskeletal Disorders (MSDs) in the respondents.

The research population was the spring production industry workers in Menganti District, Gresik Regency. The object of this research was the total population of a number of 23 workers in the production process who were willing to be respondents. This research was conducted in December 2019 until February 2020. Variables used included work duration, physical workload, and musculoskeletal disorders felt by workers after completing their working activities. The independent variables were work duration and physical workload. Meanwhile, the dependent variable was the Musculoskeletal Disorders (MSDs).
Data on musculoskeletal disorders were obtained through observation, interviews, and questionnaires. Workers were observed to find out their work duration and physical workload obtained while doing work. In addition to observation, data collection techniques were conducted by distributing questionnaires and conducting interviews. Initial questionnaire sheets of individual characteristics were addressed to the research respondents. Meanwhile, theinterview was conducted to the owner of the company to find out the company's research brief.

The work duration was calculated in accordance with the working period -, then the physical workload assessment was obtained based on measurements using calorimeter to calculate the assessment of calorie needs when doing working activities. Afterwards, proceeding to fill in the Nordic Body Map (NBM) assessment sheet after the workers completed their work. The completion of this assessment sheet was aimed to find out which parts of the body experiencing complaints and the level of complaints felt by each individual.

Data and information that had been obtained were then processed and interpreted in the tables, pictures, and narratives to facilitate the delivery of information and results obtained in the research. To obtain the results, an analysis of the relation among the variables was studied by applying a test of Chi-square with 0.05 as the value of $\alpha$. This study has already received an ethical clearance from the Health Research Ethics Commission of the Faculty of Dentistry, Airlangga University No: 001/HRECC. FODM/1/2020.

\section{RESULTS}

The informal sector used as the research site of this study is a spring production company. The company is one of the metal processing industry companies located in Menganti District, Gresik Regency. The company was established in 2015 in spring production for automotive, electronics, machinery, and so on. This spring production is produced for industrial use from large scale to individual scale. The production process in this company partially uses an automatic machine, while the other is carried out manually -.Moreover, the company employs an 8-hour working system from Monday to Saturday.

The company has two types of spring produced, namely spring leaves and spiral springs. Demand for the spiral springs will be huge in its automotive 
market sector. The company has a vision to be a spring manufacturer that produces high quality springs and sells them in global markets. Therefore, to pursue the production, - more workers are required to increase the production.

\section{Characteristics of Respondents}

Respondents' characteristics in this research consist of age, sex, and latest education. Table 1 displays the characteristics of the respondents.The results indicate that most of the workers are males ( $86.95 \%$ or 20 people). Most of the respondents also aged $36-45$ years (39.1\% or 9 people), the majority of whom have the latest education in middle school, accounting for $69.6 \%$ or 16 people.

Table 1. Distribution of Respondents' Characteristics in Spring Production Industry, 2019

\begin{tabular}{|c|c|c|c|}
\hline Variable & Category & $\begin{array}{l}\text { Frequency } \\
\text { (n) }\end{array}$ & $\begin{array}{c}\text { Percentage } \\
(\%)\end{array}$ \\
\hline \multirow{5}{*}{$\begin{array}{c}\text { Age } \\
\text { (years) }\end{array}$} & $\begin{array}{l}\text { Adolescent (17- } \\
25)\end{array}$ & 4 & 17.4 \\
\hline & $\begin{array}{l}\text { Early adulthood } \\
\qquad(26-35)\end{array}$ & 3 & 13.1 \\
\hline & $\begin{array}{l}\text { Late adulthood } \\
\qquad(36-45)\end{array}$ & 9 & 39.1 \\
\hline & $\begin{array}{c}\text { Early Elderly } \\
(46-55)\end{array}$ & 6 & 26.1 \\
\hline & $\begin{array}{l}\text { Late Elderly } \\
\quad(56-55)\end{array}$ & 1 & 4.3 \\
\hline Total & & 23 & 100 \\
\hline \multirow{2}{*}{ Sex } & Male & 20 & 86.95 \\
\hline & Female & 3 & 13.05 \\
\hline Total & & 23 & 100 \\
\hline \multirow{3}{*}{$\begin{array}{l}\text { Latest } \\
\text { Education }\end{array}$} & $\begin{array}{l}\text { Elementary } \\
\text { School }\end{array}$ & 2 & 8.7 \\
\hline & Middle School & 16 & 69.6 \\
\hline & $\begin{array}{l}\text { High School / } \\
\text { Equivalent }\end{array}$ & 5 & 21.7 \\
\hline Total & & 23 & 100 \\
\hline
\end{tabular}

Table 2. Distribution of Work Duration in the Spring Production Industry in 2019

\begin{tabular}{ccc}
\hline Category & Frequency $(\mathbf{n})$ & Percentage $\mathbf{( \% )}$ \\
\hline$\leq 8$ hours/day & 8 & 34.8 \\
$>8$ hours/day & 15 & 65.2 \\
\hline Total & 23 & 100 \\
\hline
\end{tabular}

\section{Work Duration}

From Table 2 about the distribution of work duration, it is shown that $65.2 \%$ or 15 workers are included in the category of $>8$ hours/day of work duration.

\section{Physical Workload}

The majority of workers or 18 workers $(78.26 \%)$ have complaints in the moderate level of physical workload.

\section{MSDs Complaints}

Of the 23 workers, the majority of them or 15 workers $(65.21 \%)$ are in the high level of pain and 8 workers (34.78) are in the moderate level of MSDs. The results on the correlation between work duration and MSDs from the 23 workers in the spring production unit are presented in Table 5 . 15 workers have a category of $>8$ hours per day of work duration, 9 workers $(60 \%)$ have high MSDs complaints, and 6 workers $(40 \%)$ have moderate MSDs complaints.

The chi-square test result gains sig $=0.029$ $(\alpha=0.05)$ which means that there is a correlation between the work duration and theMSDs complaints felt by the workers.

The correlation between physical workload and MSDs is presented in Table 6. Based on the results, 18 workers have a heavy physical workload, 10 workers $(55,6 \%)$ have high MSDs, and 8 workers (44.4\%) have moderate MSDs complaints.

Table 3. Distribution of Physical Workload Measurement Results in the Spring Production Industry in 2019

\begin{tabular}{ccc}
\hline Category & Frequency (n) & Percentage (\%) \\
\hline Moderate & 18 & 78.26 \\
Heavy & 5 & 21.73 \\
\hline Total & 23 & 100 \\
\hline
\end{tabular}

Table 4. Distribution of Musculoskeletal Disorders Complaints Measurement Results in Spring Production Industry in 2019

\begin{tabular}{ccc}
\hline Category & Frequency $(\mathbf{n})$ & Percentage $\mathbf{( \% )}$ \\
\hline Moderate & 8 & 34.78 \\
High & 15 & 65.21 \\
\hline Total & 23 & 100 \\
\hline
\end{tabular}


Table 5. Correlation between Work Duration and MSDs Complaints on Workers

\begin{tabular}{|c|c|c|c|c|c|c|c|c|}
\hline \multirow{3}{*}{ Category } & \multicolumn{4}{|c|}{ Complaints about MSDs } & \multirow{2}{*}{\multicolumn{2}{|c|}{ Total }} & \multirow{3}{*}{ Sig. } & \multirow{3}{*}{ Description } \\
\hline & \multicolumn{2}{|c|}{ Moderate } & \multicolumn{2}{|c|}{ High } & & & & \\
\hline & n & $\%$ & n & $\%$ & $\mathbf{N}$ & $\%$ & & \\
\hline $\begin{array}{c}\leq 8 \text { hours } \\
\text { per day }\end{array}$ & 2 & 25 & 6 & 75 & 8 & 100 & & \\
\hline $\begin{array}{c}>8 \text { hours } \\
\text { per day }\end{array}$ & 6 & 40 & 9 & 60 & 15 & 100 & 0.029 & Related \\
\hline Total & 8 & 65 & 15 & 135 & 23 & 100 & & \\
\hline
\end{tabular}

Table 6. Correlation between Physical Workload and MSDs Complaints on Workers

\begin{tabular}{|c|c|c|c|c|c|c|c|c|}
\hline \multirow{3}{*}{ Category } & \multicolumn{4}{|c|}{ Complaints about MSDs } & \multirow{2}{*}{\multicolumn{2}{|c|}{ Total }} & \multirow{3}{*}{ Sig. } & \multirow{3}{*}{ Description } \\
\hline & \multicolumn{2}{|c|}{ Moderate } & \multicolumn{2}{|c|}{ High } & & & & \\
\hline & $\mathrm{n}$ & $\%$ & $\mathrm{n}$ & $\%$ & $\mathbf{N}$ & $\%$ & & \\
\hline Moderate & 0 & 0 & 5 & 100 & 5 & 100 & & \\
\hline Heavy & 8 & 44.4 & 10 & 55.6 & 18 & 100 & 0.000 & Related \\
\hline Total & 8 & 34.8 & 15 & 65.2 & 23 & 100 & & \\
\hline
\end{tabular}

The finding obtained from chi-square test is $\operatorname{sig}=0.000(\alpha=0.05)$ which indicates that there is a correlation between the physical workload given to workers and the MSDs complaints felt.

\section{DISCUSSION}

Hardened steel is used to make springs. The production of spring can use pre-hardened steel before forming the springs or can harden the springs after the formation process. Usually, music wire, stainless steel, chrome silicon, oil tempered wire, or chrome vanadium are used as the spring steels, depending on the conditions.

The spring production process starts with coiling the springs which can be carried out in a cold or heated wire. Cold winding uses a wire in room temperature and carries out the winding process around a shaft. Meanwhile, the hot winding for the thicker wire or bar stock is made by heating the metal beforehand to add the wire flexibility, and then the extremely hot steel is coiled around a shaft. The last step is coating. Avoiding corrosion is carried out by coating the whole surface with liquid rubber or plating the surface with another metal such as chromium or zinc.

Spring production process is carried out by automatic and manual machines. Results of the interviews suggest that many workers working on manually operated machines.complain about MSDs The manual engine still uses human power as its tool drive. In addition to it, heavy loading felt by workers increases the risk of complaints due to the increased work duration.Therefore, many manual machine workers feel the MSDs.

The spring production industry, as one of the informal sector employment, requires considerable efforts and energy for its workers. The production process of this industry uses a lot of repetitive activities with a continuously standing position and movements such as taking and arranging repeatedly. The work duration and the burden given to the workers are matters that need to be considered to prevent the emergence of MSDs.

\section{Characteristics of Respondents}

The characteristics of respondents include age, sex and the latest education. Nurmianto (2004) states that the peak of muscle strength in men and women is reached by the ages of 25-30 years. To workers, the ages of 50-60 years only produce muscle strength by $75-85 \%$. Generally, various complaints will be felt by someone aged over 35 years.

Sex is one factor related to muscle endurance between female and male. Sex is closely related to musculoskeletal disorders complaints. This is because, physiologically, the ability of males' muscles is stronger than that of the muscles in female.

\section{Work Duration}

In general, a person works for 6-8 hours per day. The remaining 16-18 hours is the time spent to live with family and to socialize with the community, to 
rest, to sleep, and others. An individual will normally work in a good manner for 40-50 hours a week (Suma'mur, 2013).

The work duration is a period of time or length of time that the workers spend in a place of work. Extending work duration by exceeding one's ability will cause longer work duration, which is not necessarily followed by maximum performance, efficiency, and profitability. Dealing with the work duration in a week, an individual will normally work in a good manner for 40-50 hours if the workduration per day is between 6-8 hours. If the work duration exceeds this, it more likely causes negative concerns to arise for the workforce.

The results present that the length of hours working with MSDs complaints can infer that there is a significant correlation between the work duration and the MSDs complaints in workers in informal sector. The results of the test obtains the $p$ value which is slightly than the significance value which has been determined with a high correlation score.

Randang, Kawatu, and Sumampouw's (2017) study describes that the longer the job period, the greater the hazard earned and the longer the time needed to recover the energy.

Based on observation, all respondents do their work repeatedly which takes place six days a week. The work carried out uses quite high energy because many tools are used manually in completing the work. If this activity lasts for years, it will certainly increase the risk of MSDs felt by workers.

Regarding the aforesaid, it is shown that based on the findings of the study on the work duration, the majority of respondents more often work for $>8$ hours per day. The break time for workers is at 12:00 to 13:00 hours every day. The workdays are from Monday to Saturday.. Workers who extend working hours outside their regular work duration have reasons to do so, one of which is to increase their income.

In this research, it is found that the majority of respondents work more than 8 hours per day. by doing so, it is possible for them to experience musculoskeletal complaints. This research conforms what Wijayanti (2013) has conducted to farmers about the relation of musculoskeletal complaints and work duration that shows there is a correlation between these two aforesaid matters.

Furthermore, this research is in line with research from Suma'mur (2013) that musculoskeletal complaints will increase if a person's working hours is longer. This, and then, will reduce work productivity, result in fatigue, and can lead to work-related illnesses or work-related accidents. Productivity of a person will start to decline after working for 4 hours. Therefore, taking a rest and the utilizing the opportunity to eat will be able to restore the body's condition. The specified resting time is half an hour break after consecutive 4 hours of working. Besides, the maximum work duration of a person to work effectively is 8 hours per day,including the resting hours.

Tana, Delima, and Tuminah (2009) explain that the most influential factors to the complaints of MSDs in the garment industry workers are the work duration and working postures. The working hours in a day are also noticed to give a contribution to the complaints of MSDs.The result of the said study is in line with previous research conducted by Fajri and Yuantari (2015), explaining that the results of the static test between work duration and musculoskeletal complaints show a significantly and positively strong enough correlation, meaning that the more hours spent at work, the higher the emergence of musculoskeletal complaints to be felt by the workers. Workers with workduration of $>8$ hours per day experience severe musculoskeletal disorders, while workers with work duration of $<8$ hours per day experience mild musculoskeletal disorders.

\section{Physical Workload}

According to Tarwaka (2015), the human body is created to be able to perform daily working activities. Muscle mass that weighs almost more than half of body weight allows humans to be able to move the body and do work. However, it also means that the body will receive burden from outside the body, both in the form of physical workload and mental burden.

Workload is any job that requires muscle strength and thought of the subjects. The workload given to workers must be adjusted to their physical and psychological abilities, so such abilities will not affect the workers' health condition (Setyawati, 2010).

Moreover, measuring the heat rate during work is carried out with physical workload measurement as the method to assess cardiovascular strain. This can be carried out by checking the pulse of the radial artery at the wrist. An increased pulse is caused by the physical workload through the number of muscles involving the static load received and the temperature pressure from the work environment; the pulse will change in tune with changes in loading (Tarwaka, 2015). 
The assessment of physical workload is based on an assessment of the level of calorie requirements as well as on the energy expenditure. The results of the study show that most workers (18 workers or $78.26 \%$ ) are in the category of moderate level of physical workload.

Regarding this, as it is shown in the results of the study, there was a significant correlation betweeen thephysical workload and MSDs in informal sector workers. The hypothesis is propped by the research findings that describes the improved workload will be accompanied by improvement in musculoskeletal problems (Wiyatno, 2011).

The theory is in line with Tarwaka (2015) which shows that each person's working ability is highly dependent on the level of skill, physical fitness, nutritional status, sex, body size, and age of the workers concerned. In general, age is related to someone's working period. When the working period increases automatically, the age of the worker will increase and vice versa. Moreover, the increased age and working period of a person will result in the decreased muscle strength and endurance, and therefore, the risk of muscle complaints occurs. This is one of the causes related to the results obtained where respondents with a moderate category of workload experience high risk level musculoskeletal complaints. High working pressures are frequently inevitable and may lead the workers to experience discomfort within their limbs (Aeni, 2017)

Another research conducted by Bobaya, Kandou, and Rattu (2017) regards the correlation between physical workload and the complaints of MSDs on loading and unloading labors in Manado Harbor. The research was conducted to one hundred respondents. From this study, it is shown that there is a correlation between physical workload and MSDs on loading and unloading labors. This happens because musculoskeletal complaints often arise if the muscles receive excessive workload pressures.

Inappropriate workload for employees is one of the key sources of social error, which makes reduction in quality and working performance. Thus, the workload dimension is a critical factor in minimizing work-related incidents and injuries as well as damages and costs in the management (Khandan et al., 2018).

Utami, Anitasari, and Endhiarto (2017) find a similar result in the form of a significant relation between workload and MSDs among farmers in Ahuhu Village, Meluhu District, Konawe Regency. This research is in line with what was done by
Putra (2015) which shows that lift-haul labors in PT Bahama Lasaka Ceper Klaten shows the relation among physical workload and MSDs that occur to workers.

Another research conducted at the Shoe Factory in Nganjuk shows a p value of 0.009 which indicates that the physical workload is related significantly to MSDs complaints, The higher the workload, the more serious the workers suffer from MSDs problems (Putri, 2019). The findings of a study proposed by Aulia Tjahayuningtyas show a relation between the workload and MSDs issues (Aulia, 2019). According Heni, Lilis, and Tuti (2020) also shows the significant relation between the physical workload and MSDs complaints in nurses. The greater the physical workload, the greater the grievances of MSDs experienced by nurses (Heni, Lilis and Tuti, 2020).

\section{Musculoskeletal Disorders (MSDs) Complaints}

Subjective complaints in muscles are one of the indicators in evaluating the application of ergonomics. The job factors that affect muscle strength and cause muscle complaints include unnatural working positions, repetition of work on one type of muscle, excessive exertion, static working positions, and the Working behaviour and working hours (Suma'mur, 2013).

The assessment of musculosketal disorders complaints is conducted using NBM Questionnaire. The NBM Questionnaire Sheet has 4 categories to assess the level of pain that the respondents experienced, namely score 1 (not hurt), score 2 (somewhat sick), score 3 (sick), and score 4 (very sick). These will be shown on 28 parts of the body.

All workers in the production unit or 23 respondents state to have experienced MSDs in parts of their body after completing their work activities. The work is mostly dominated by male workers because the production process uses many manual machines, and therefore require muscle strength. This type of working activities will certainly cause injury to the muscles, joints, ligaments, and tendons (Tarwaka, 2015). These are commonly referred to as Musculoskeletal Disorders complaints that arise in the musculoskeletal system, in which condition discomfort or pain may arise.

Based on the results of the assessment of MSDs complaints using NBM questionnaires in the production section of the company, it is revealed that most respondents suffer from musculoskeletal complaints in a high-level category. There are 15 
workers suffering from high-risk complaints. The moderat risk is that there are about 8 workers. The complaints most widely felt are on the waist, back, neck, and left shoulder. This is due to the working factors.

Indications of MSDs can be in the forms of pain, anxiety, tingling, death of taste, burning, swelling, stiffness, cramps, grip strength in hand moving, changes in body balance as well as loss of flexibility. If the complaints are not controlled properly, they can interfere the workers' body either because it has occurred or is felt in the long term.

\section{CONCLUSION}

The results showthe relation between work duration and physical workload with Musculoskeletal Disorders (MSDs) among workers in informal sector.. In addition, MSDs have a high risk level of complaints in some workers of the informal sector.

\section{ACKNOWLEDGEMENTS}

The writers would like to thank the respondents and workers of the spring production industry in Menganti Gresik District, as well as those who have helped carry out this research to completion.

\section{REFERENCES}

Aeni, H. F. A. (2017) 'Hubungan Sikap Kerja Duduk dengan Keluhan Nyeri Punggung Bawah pada Pekerja yang Menggunakan Komputer', Jurnal Kesehatan, 8(1), pp. 887-894.

Alma, B. (2001) Kewirausahaan. Revisied. Bandung: Alfabeta.

Aulia, T. (2019) 'Faktor yang Mempengaruhi MSDs pada Pekerja Informal', The IndonesianJournal of Occupational Safety and Health., 8(1), pp. $1-10$.

Bird, E. J. F. and Germain, L. (2005) Kepemimpinan Pengadilan dan Kerugian Praktis. 3rd edn. Edited by W. Abdullah. Jakarta: PT. Devnegraha.

Bobaya, W., Kandou, G. D. and Rattu, A. J. M. (2017) 'Hubungan Antara Status Gizi, Umur dan Beban Kerja Fisik Dengan Keluhan Muskuloskeletal Pada Tenaga Kerja Bongkar Muat di Pelabuhan Manado', Community Health, 3(1), pp.1-8.

Fajri, P. N. and Yuantari, M. C. (2015) 'Faktor Faktor Sekunder yang Berhubungan dengan Keluhan MuskuloskeletalPekerja Laundry di Kelurahan Muktiharjo Kidul Semarang',
Scientific Article. Semarang: Faculty of Health Universitas Dian Nuswantoro.

Health and Safety Authority (2015) Manual Handling Infographics. Dublin: Health and Safety Authority.

Heni, F. A., Lilis, B. and Tuti, N. (2020) 'Hubungan Beban KerjaFisik dengan Keluhan Gangguan Muskuloskeletal pada Perawat di RumahSakit', The Indonesian Journal of Occupational Safety and Health. 9(1), pp. 88-94.

Icsal, M., Sabilu, Y. and Pratiwi, A. D. (2016) 'Faktor yang Berhubungan dengan MSDs pada Penjahit WilayahPasar Panjang Kota Kendari Tahun2016', Jurnal Ilmiah Mahasiswa Kesehatan Masyarakat, 1(2), pp. 1-8.

International Labour Organization (2013) The Prevention of OccupationalDisease. Genewa: International Labour Organization.

Khandan, M. et al. (2018) 'Subjective Workload\&Musculoskeletal Disorders among Workers of a Manufacturing Company in Iran', Biotech Health Sciences, 5(1), pp. 1-6.

Maharja (2015) 'Analisis Tingkat Kelelahan Kerja Berdasarkan BebanKerja Fisik Perawat di Instalasi Rawat Inap RSUHaji Surabaya', The Indonesia Journal of Occupational Safety and Health, 4(1), pp. 93-102.

Notoatmodjo, S. (2007) Kesehatan Masyarakat Ilmu dan Seni. Jakarta: Rineka Cipta.

Nurmianto, E. (2004) Ergonomi Konsep Dasar dan Aplikasinya. 2nd edn. Surabaya: Guna Widya.

Putra, E. N. P. (2015) Hubungan Beban Kerja Fisik dengan keluhanMusculoskeletal pada Tenaga KerjaAngkat-Angkut PT. Bahama Lasakka Ceper Klaten. Undergraduate Thesis. Fakultas Kedokteran, Universitas Sebelas Maret.

Putri, P. S. (2019) 'Hubungan beban kerja fisik dengan Keluhan MSDs pada Pekerja di PabrikSepatu Nganjuk', Jurnal Keperawatan Muhammadiyah, 4(1), pp. 63-67.

Randang, M. J., Kawatu, P. A. T. and Sumampouw, O. J. (2017) 'Hubungan antara Umur, Masa Kerja dan Lama Kerja dengan Keluhan m\ Muskuloskeletal pada Nelayan di Desa Talikuran Remboken Minahasa', Media Kesehatan, 9(3), pp. 1-8.

Setyawati, K. (2010) Selintas Tentang KelelahanKerja. Yogyakarta: Amara Books.

Suma'mur, P. K. (2013) Ergonomi untuk Produktivitas Kerja. Jakarta: CV Haji Masagung.

Tana, L., Delima and Tuminah, S. (2009) 'The Relation between Work Duration and Work Position to Neck 
and Upper Extremity MusculoskeletalSymptoms among Female Garment Workers in North Jakarta', Bulletin of Health Research, 37(1), pp. $12-22$.

Tarwaka (2010) Ergonomi Industri Dasar- dasar Pengetahuan Ergonomi dan Aplikasi di tempat Kerja. Surakarta: Harapan Press.

Tarwaka (2015) Ergonomi Industri, DasardasarPengetahuan Ergonomi dan Aplikasi di Tempat Kerja. 2nd edn. Surakarta: Harapan Press.

Utami, E. S., Anitasari, D.and Endhiarto, T. (2017) 'Determinants of Corporate Bond Rating in Indonesia:Additional Evidence', Review of
Management\&Entrepreneurship, 1(2), pp. 27-33.

Wijayanti, T. S. (2013) Hubungan Antara Nyeri Muskulosekeletal Dengan Kondisi Stasiun Kerja dan Ukuran, Serta PosisiTubuh Petani. Undergraduate Thesis. Fakultas Ilmu Sosial dan Ilmu Politik, Universitas Airlangga.

Wiyatno, H. T. (2011) Hubungan antara Beban Kerja dan Sikap Kerja dengan Keluhan Muskuloskeletal pada Buruh Panggul di Kawasan Industri Candi KotaSemarang. Undergraduate Thesis. Fakultas Keolahrahaan, Universitas Negeri Semarang. 